\title{
O comunismo e outros perigos: memórias sobre o medo entre católicos
}

\author{
Carla Simone Rodeghero*
}

Este artigo apresenta e analisa lembranças de um grupo de católicos gaúchos a respeito da pregação da Igreja contra o comunismo e do medo que era sentido em relação a ele, no período entre o final da Segunda Guerra e o golpe de 1964. As entrevistas - que foram um misto de história de vida e entrevista temática - fizeram parte de uma pesquisa mais ampla, preocupada em entender a recepção do anticomunismo entre as pessoas comuns, no caso, fiéis e membros do clero católico (Rodeghero, 2002).

A maior parte dos entrevistados foram pessoas que passaram parte de sua vida na zona rural ou em pequenos municípios do estado do Rio Grande do Sul, tendo um restrito acesso a informações e estando integradas em sociedades nas quais a presença da Igreja e a autoridade do padre eram muito marcantes. Procurou-se averiguar de que forma a persistente pregação do clero em relação ao comunismo atingia os fiéis. Percebeu-se que estas pessoas, ao serem questionadas sobre o comunismo e o anticomunismo, mesclam em suas reflexões elementos - transformados - do discurso oficial e elementos novos, que permitem trazer para perto da vida diária o que seria o perigo do comunismo.

* Professora da Universidade Federal do Rio Grande do Sul-UFRGS. 
Dentro deste quadro, o artigo apresenta e analisa parte das falas dos entrevistados, buscando explorar as seguintes questões: como era encarado o perigo comunista? A que outros perigos ele era associado? Qual era o universo cultural a partir dos qual os sujeitos entrevistados falavam? Que relação eles tinham com o tema comunismo/anticomunismo? Por meio dessas questões, buscam-se explicitar os pressupostos que embasavam as "leituras" que essas pessoas fizeram/fazem sobre este tema.

\section{Comunismo sem comunistas}

Nas falas dos entrevistados ${ }^{1}$ não há, praticamente, avaliações sobre a ação do Partido Comunista no Brasil. Parece, salvo em dois casos, não haver conhecimento sobre a existência de comunistas nas cidades onde os entrevistados vivem. Alguns exemplos são ilustrativos deste quadro. D. Laurindo Guizzardi, que na ocasião da entrevista era bispo da diocese de Bagé, achou graça de ter receado que os comunistas chegassem a um lugar calmo como sua terra natal, a pequena Nova Bassano, na Serra gaúcha. "Era uma coisa meio nebulosa porque a gente não sabia nem dizer onde era. Eu esperava que um dia ou outro aparecessem os comunistas por aí, em Nova Bassano [risos]”.

Pe. Moisés Mocelin, de Passo Fundo, disse não lembrar de quem eram os comunistas no Brasil. Questionado sobre Prestes, lembrou que se falava um pouco sobre ele, não muito. Referiu-se, todavia, à Coluna Prestes: "a gente dava graças a Deus que terminou, que ele foi vencido". Além disso, contou também que "a gente sabia da Intentona, do Prestes, queria botar o comunismo". Irma e Nelso Ribeiro lembraram que se falava a respeito de Prestes e também que em Cacequi, assim como em Alegrete onde vivem, havia comunistas. No último caso, eles citaram o nome de Policarpo, ${ }^{2}$ irmão de duas outras pessoas entrevistadas, as senhoras Perciliana e Vitalina da Costa, referindo-se a ele como "um que era [comunista] declarado". Não lembravam se existia o partido. Irma tinha a

1 A relação dos entrevistados e dados complementares sobre as entrevistas encontram-se ao final do artigo.

2 Trata-se de Policarpo Pereira da Costa. Seu nome consta de uma lista de militantes comunistas atuantes no período da legalidade do PCB (1945-1947). Ver: MARTINS, 2007. 
impressão de que "eles não se declaravam". Este foi o único comunista gaúcho citado pelo conjunto dos entrevistados.

Horacil Dutra, de Bagé, por sua vez, não lembra se existiam comunistas em sua cidade ou se o partido estava organizado lá. Lembra, porém, que Luiz Carlos Prestes era famoso. Narciso Tesser, de Marau, questionado sobre nomes de comunistas, disse que o adjetivo comunista era usado como forma de insulto, na comunidade onde ele vivia: "Olha, geralmente quando existia aquelas rixas de... aquela coisas, um chamava de comunista prá o outro. E o cara que era chamado de comunista, ele se incomodava". Depois de comentar sobre o que os padres falavam a respeito do comunismo, Ida Carlesso, religiosa da Congregação do Imaculado Coração de Maria, entrevistada em Santana do Livramento, foi questionada sobre "quem eram os comunistas" e respondeu que isso não era explicado. "Não, só diziam 'comunista', mas não diziam quem. Não chegavam a dizer quem". E logo a seguir: "Acho que eles [os padres] tinham medo também de falar, de dizer".

Vários entrevistados fizeram referências a Luiz Carlos Prestes. Pe. Guerino Parizzoto, de Passo Fundo, mencionou que Carlos Prestes era "O chefe, o presidente do partido" o qual, segundo ele, foi suprimido em 1944 ou 1945. Pe. Firmino Dalcin, entrevistado em Bagé, contou sobre a apreensão provocada por um comício de Prestes em São Leopoldo, a mesma cidade onde estava sediado o seminário católico onde ele estudava. O nome de Prestes apareceu também em outra situação. $\mathrm{Na}$ conversa com a irmã Ida e com Dorvalina Peres, em Santana do Livramento, a primeira tentava lembrar nomes de presidentes da República que governaram durante a sua infância. Explicou que como a família não tinha acesso a televisão, rádio e jornal, muitas vezes era demorado para saber se havia trocado o presidente da República, o governador, o prefeito. Ida lembrou que "o tempo que eu ia pra escola era o Getúlio Vargas. Depois tinha o Carlo Prestes, não sei o que que ele era". Interferi: "Ah, o Luiz Carlos Prestes era comunista". E Ida complementou, "pois é. Esse aí era... Isto. O Carlo Prestes era o comunista!" É interessante notar que ela afirma que Prestes era "o" comunista e não "um" comunista. O uso do artigo definido "o" nessa fala permite argumentar que o comunismo era uma coisa muito abstrata que, para a maioria das pessoas entrevistadas, podia ser associado à figura de Prestes. Fora dele era difícil achar outros portadores desta "marca". 
Se era difícil relacionar o comunismo a outras pessoas além de Prestes, quais os lugares que, na memória e nas reflexões dessas pessoas, foram associados ao comunismo? Foi possível ver, a partir das lembranças de alguns padres entrevistados, a forte presença do México e da Espanha no imaginário anticomunista do clero católico. A recorrência da relação comunismo - anticlericalismo - México - Espanha também se manifestava em pronunciamentos de autoridades eclesiásticas, bem como em documentos papais. Mesmo que se tratasse de situações nas quais os conflitos entre Estado e Igreja não fossem mediados pelo comunismo, como foi o caso do México na década de 1920, os relatos sobre a perseguição à Igreja foram incorporados àqueles referentes às perseguições promovidas por governos comunistas, como explorei em outro estudo (Rodeghero, 2006). Mas, no conjunto das entrevistas realizadas, o comunismo também foi situado na Rússia e em Cuba. Uma ou outra referência à China, à Hungria, à Iugoslávia, à Albânia.

Gabriel Mocelim, de Passo Fundo, comentou sobre Brizola que "a formação dele era da Rússia". José Rigo, de Marau, lembrou que "era apontado que como o comunismo tomou conta da Rússia, estava se espalhando pelo mundo todo". Carino Corso, também de Passo Fundo, comentou que "o comunismo nasceu na Rússia, no ano de 1917. No ano em que eu nasci, veio o comunismo". Respondendo a indagação a respeito dos padres falarem ou não a respeito da Rússia, Dona Iaiá, em Bagé, assim se manifestou: "Falavam da Rússia, onde eles disseram que a Nossa Senhora disse que se a Rússia rezasse, ela se converteria. E se converteu mesmo. Ela ia salvar a Rússia do comunismo e salvou mesmo".

D. Laurindo contou que "vinham ecos da Rússia, disso e daquilo. Então, o que a gente guardava como herança daquilo que ouvia, era que realmente o comunismo era uma coisa inumana, o comunismo na sua experiência russa, basta dizer que em 1917, milhões de pessoas foram eliminadas". Ele também se referiu à Hungria, especialmente a um fato que mobilizou a Igreja Católica em termos internacionais, que foi a prisão do cardeal Aloysius Stepinac e referiu-se, ainda, à perseguição que a Igreja sofria nos países da Cortina de Ferro.

Os lugares Rússia e Cuba apareceram nas reflexões de Horacil, que lembou que "naquela época, a gente ouvia falar muito da Rússia. A Rússia era o país, o centro do comunismo e hoje, graças a Deus, o papa conseguiu...” Na seqüência, falou sobre Cuba e a visita que o papa João Paulo 
II fizera a ela pouco tempo antes da realização da entrevista. Ele também citou o nome do PCB e do PC do B, mas estava se referindo à existência desses partidos comunistas na atualidade.

No caso de Cuba, nas várias vezes em que ela foi citada, foi possível ver que não havia em sua relação uma aversão automática. A existência de uma tímida "simpatia" por Cuba, dentro da Igreja, pode ter sido resultado de diferentes processos: um anterior à vitória da revolução, quando os católicos torciam pela sorte dos guerrilheiros e não vislumbravam um alinhamento de Fidel com a União Soviética; outro posterior, representado pela recepção do livro Fidel e a Religião de frei Betto, no auge da Teologia da Libertação. É possível que em meio a esses dois processos, outro tenha estado em ação, atingindo especialmente aqueles grupos da Ação Católica que assumiram uma postura de esquerda e rejeitaram o anticomunismo tradicional. Num âmbito ainda mais amplo, é preciso não desprezar as esperanças de transformação social que circulavam no Brasil nos anos anteriores ao golpe de 1964, dentro das quais a Revolução Cubana significava um marco. Estas esperanças podem ter atingidos setores católicos, especialmente entre a juventude.

Veja-se como o caso de Cuba aparece na análise de padre Holmes Conzatti, entrevistado em Alegrete: “... Depois, com Fidel, a gente começou a olhar não o comunismo enquanto ateu [...]. A gente vê, por exemplo, no caso da Igreja Católica, o período da Teologia da Libertação, das CEBs. Então, ali, os padres que eram da Teologia da Libertação, eles olhavam Cuba com muita simpatia. Por isso, durante o tempo do estado, perseguição, da revolução, muitos padres foram presos, tudo por causa disso aí. Havia uma repressão muito grande". Pe. Moisés também fala sobre Cuba: "Fidel Castro, até, no começo, a gente foi quase a favor e depois que ele mudou o sistema lá, etc., mas ele deve ter tido sua razão".

Essas referências mais "concretas" ao comunismo, à liderança de Luiz Carlos Prestes, à Rússia, Cuba, China, Hungria ocuparam, entretanto, lugar muito pequeno no seio das lembranças a respeito de comunismo e anticomunismo, e se mostraram muito mais presentes nas reflexões de membros do clero. Para os leigos parece que a maior parte das memórias é atravessada por uma lógica que pode ser resumida numa frase dita por Carino Corso: "Então, a gente combatia muito o comunismo naquele tempo, embora não existisse comunista". 
Daí se pode concluir que existia medo do comunismo, apesar de não haver conhecimento sobre a existência de comunistas. Ou indo além, em muitos casos, depreende-se que havia comunismo apesar de não existirem comunistas. Com uma única exceção, o já mencionado Policarpo, os comunistas locais não eram conhecidos. Os partidos pareciam não ter atuação. A maior parte dos entrevistados não fez referências diretas ao PCB ou depois ao PC do B e a outros agrupamentos da esquerda brasileira que surgiram na década de 1960. Com base nestes exemplos, vê-se um descolamento entre o objeto que gerava medo e o medo sentido, que podia ser maior ou menor, dependendo da pessoa. Uma das possíveis explicações para tal fenômeno é a que a falta de maior clareza sobre um certo perigo ou inimigo não diminui as razões para que as pessoas sintam medo dele. O desconhecimento pode, na verdade, gerar um temor ainda maior. Mas, nessa situação particular que está sendo analisada, também é possível dizer que o perigo representado pelo comunismo ganhava corpo na associação com outros perigos e não naquilo que normalmente se poderia classificar como atividade de um partido ou de grupos comunistas. Daí a necessidade de buscar quais eram esses perigos e também de acompanhar a presença deles tanto nas reflexões dos entrevistados, quanto em documentos oficiais da Igreja, como é o caso das encíclicas papais que tratam do tema.

\section{Comunismo: inimigo da Igreja, da família e da propriedade}

A localização do perigo representado pelo comunismo na forma como isso foi expresso nas entrevistas de história oral coincide, em muitos casos, com as linhas básicas do discurso católico anticomunista, já que nos dois universos são enfatizados temas como a destruição das famílias, a expropriação e, especialmente, o anticlericalismo, sendo este último mesclado com ateísmo. Em outros casos, o perigo aparece associado a situações bem diferentes dessas.

Com base em estudos anteriores sobre o tema é possível dizer que o discurso católico anticomunista no Brasil não levava muito em conta as mudanças nas posturas políticas dos comunistas - particularmente do PCB - ao longo do tempo e nem fazia grandes distinções entre o período 
em que o partido atuou na legalidade e quando ele viveu na clandestinidade. Isso porque o tema do comunismo era geralmente tratado de uma forma bastante abstrata no que se refere ao sujeito ou aos grupos atingidos pelas críticas. Isso não impedia, no entanto, que pronunciamentos de autoridades, como arcebispos e bispos, ou ainda de organizações como a Liga Eleitoral Católica (LEC) fossem feitos como resposta a ações ou projetos específicos dos comunistas.

Um exemplo é a crítica católica à proposta de União Nacional defendida pelos comunistas no ano de 1945. Na ocasião, a LEC deixou claro que não acreditava que os comunistas estivessem propondo calma e conciliação. Eles, como lobos, estariam se vestindo de cordeiros. Mas, em termos gerais, pode-se dizer que o anticomunismo católico brasileiro tratava do comunismo em termos mais amplos, como um grande mal que estava presente nos mais diversos campos da vida social e política, visando subverter a ordem estabelecida - e considerada certa - para implantar um regime sem Deus, sem propriedade, sem pátria, sem família.

Um dos focos desta visão mais ampla e abstrata era o anticlericalismo. A relação entre comunismo e anticlericalismo foi levantada tanto por membros do clero quanto por leigos. Nas entrevistas com membros do clero, houve a já mencionada ênfase nas manifestações anticlericais ocorridas no México e na Espanha, respectivamente nos anos 1920 e 1930, ênfase e interpretação bastante presentes em documentos da hierarquia católica.

Das falas da maior parte dos leigos entrevistados, foi possível captar uma percepção compartilhada de que o comunismo era mau porque estava contra os padres, contra a Igreja, contra Deus. Vê-se, ainda uma mescla de anticlericalismo com laicismo e ateísmo. Narciso, por exemplo, lembra que numa localidade onde todos eram católicos, os que estivessem "fora da religião" eram considerados comunistas. Uma acusação um tanto pesada, parecida com aquela trazida por Jandir Zanotelli, entrevistado em Pelotas. $\mathrm{Na}$ comunidade onde ele nasceu, entre descendentes de imigrantes italianos, se dizia: "aquele não foi à missa, logo é comunista". Horacil, por sua vez, contou que o comunismo era uma coisa que aterrorizava "porque eles combatiam a religião". Foi esta a primeira característica do comunismo que ele lembrou. Augusto Huber, em Bagé, depois de falar a respeito da repartição das propriedades, comentou que "as pessoas tinham medo do comunismo por causa da religião, contra a religião" e que "eles perseguiam muito os padres". 
É interessante notar como na encíclica escrita exclusivamente para combater o comunismo, a Divini Redemptoris, de 1937, os temas que aqui estão sendo explorados aparecem muito próximos uns dos outros - nos três primeiros parágrafos, em que se descreve a doutrina comunista - e fazem parte dos pressupostos que justificam a crítica católica ao comunismo. $\mathrm{O}$ texto inicia enfocando a questão do materialismo para tratar, em seguida, da autoridade, da propriedade e então das repercussões na família. Quanto ao materialismo presente na doutrina comunista: "esta doutrina proclama que não há mais que uma só realidade universal, a matéria formada por forças cegas e ocultas que, através da sua evolução natural, se vai transformando em planta, em animal, em homem [...]. É, pois, evidente, que neste sistema não há lugar sequer para a idéia de Deus" (Pio XI, 1965, p. 9).

Na seqüência, a encíclica considera que descartando a vida espiritual, o comunismo privaria a pessoa humana da sua dignidade e de todos os freios de ordem moral. $\mathrm{Na}$ relação entre os cidadãos, por sustentar o princípio da igualdade absoluta, o comunista rejeitaria toda a hierarquia e autoridade, tanto a procedente de Deus, quanto aquela dos pais. Indo além, a questão da propriedade é tematizada: "Nem aos indivíduos se concede direito algum de propriedade sobre os bens naturais ou sobre meios de produção; porquanto, dando como dão origem a outros bens, a sua posse introduz necessariamente o domínio de um sobre os outros. E é precisamente por esse motivo que afirmam que qualquer direito de propriedade privada, por ser a fonte principal da escravidão econômica, tem que ser radicalmente destruído" (Idem, p. 10).

Entrando no tema da família, a argumentação de Pio XI é de que a rejeição do "caráter sagrado da vida humana" na doutrina comunista atingia, por conseqüência, o caráter do matrimônio e da família. Segundo o papa, a forma do comunismo destruir a família seria através de concepções de que o matrimônio não passava de um contrato como outro qualquer, podendo desta forma ser desfeito. Esta facilidade em desfazê-lo é que tornaria os cônjuges menos responsáveis em relação ao casamento. No que se refere aos filhos, estava em jogo o papel da mulher, que sob o comunismo seria tratada da mesma forma que o homem, atirada à "agitação da vida pública”. Ela não seria mais responsável pelo cuidado do lar e dos filhos, cuja educação ficaria à mercê do Estado.

Alguns entrevistados se manifestaram sobre a destruição das famílias. José Rigo comentou que o comunismo "trazia uma aflição que era a 
destruição da família". A irmã Ida contou que se falava que "eles iriam levar todas as crianças para educar conforme eles queriam, conforme o comunismo e que ninguém ficava com as crianças em casa [...], pra botar na cabeça das crianças uma educação diferente". Algo parecido foi colocado por Vitalina: "amedrontavam a gente com o comunismo, que tiravam os filhos, que o governo lá tirava os filhos e deixava os filhos para educar".

O comunismo representava, então, a destruição da família, seja pela liberalização dos laços do casamento ou pela destituição do direito dos pais de educarem seus filhos. Mesmo que no Brasil não existissem leis anticlericais nem "destruidoras" da família, como a lei do divórcio, ainda assim, o discurso católico anticomunista seguia as combatendo, pois via tendências nessa direção. E na memória de muitos fiéis católicos ficou presente esta marca. Sem religião, sem autoridade paterna e sem a segurança social e individual proporcionada pelo casamento, as sociedades estariam expostas à propaganda subversiva.

No que se refere à ameaça que o comunismo representava à propriedade privada, Narciso lembra que sob o comunismo "todos eram iguais". Irma conta que "se apossavam de tudo, o que era teu era meu, o que era meu era teu, essa coisa toda. Ninguém era dono do que era seu, como está acontecendo em certos pontos agora”. Irmã Ida, por sua vez, lembra que sentia "medo de que o comunismo viesse para cá também, tomasse parte porque aí, eles diziam assim, então eles tiravam tudo das famílias. Iam tirar tudo. Depois eles repartiam conforme precisasse para todo mundo. Ninguém ficava dono de nada." É interessante lembrar que Ida contou, em outro momento da entrevista, que como seu pai não tinha terra, a família tinha migrado por diversos municípios gaúchos e catarinenses em busca de trabalho e de terra.

O mesmo medo que esta filha de um agricultor sem terra sentia em relação ao fato de que "ninguém era dono do que era seu" pode ser captado no relato de Augusto, que fala do medo que os fazendeiros sentiam em relação ao comunismo: "quem tivesse duas casas tinha que dar uma para o outro. Tinha que estar dividido. Então, muita gente que tinha, os fazendeiros mesmo, como é que ia ser? Teriam que repartir tudo isso?" Ou seja, não era necessário ser proprietário para ter medo de perder a propriedade ou de viver numa sociedade onde ela não posse possuída e usufruída privadamente. 
Os temas levantados nas entrevistas e agora cruzados com a encíclica Divini Redemptoris - comunismo versus religião, família e propriedade - vinham sendo objeto da preocupação na Igreja desde antes do comunismo ter se corporificado no regime soviético e muito antes da deflagração da Guerra Fria. Já em 1891, por meio da Rerum Novarum, por exemplo, Leão XIII chamava a atenção para o problema da doutrina comunista ser contrária ao direito natural. $\mathrm{O}$ direito natural seria aquele que precede a organização do Estado "porque o Estado é posterior ao homem e antes que ele pudesse formar-se já o homem tinha recebido o direito de viver e proteger sua existência" (Leão XIII, 1978, p. 14).

Nessa lógica, encadeia-se a defesa do direito de propriedade e do poder do pai na família. Segundo Leão XIII, Deus concedeu a terra para todo o gênero humano, mas não para que "a dominassem confusamente todos juntos [...]. Quis deixar a limitação da propriedade à indústria humana e às instituições dos povos" (Idem). O casamento também teria base no direito natural, por ter como fim principal colocar em prática o "crescei e multiplicai-vos" da ordem divina. Disso se conclui que "a sociedade doméstica é anterior à sociedade civil e, para o homem, enquanto chefe de família, o direito de propriedade é ainda mais fundamental. É com base nesse direito que o pai dá conta do dever sagrado de sustentar os filhos e zelar pelo seu futuro, formando um patrimônio" (Rodeghero, 1998, p. 26).

Voltando para a Divini Redemtoris: o texto de 1937 trata, ainda, dos casos de perseguição à Igreja, entendendo-os como uma das funestas conseqüências da aplicação da doutrina comunista, a qual seria difundida por meio de propaganda bem organizada e sedutora e teria seu caminho preparado pelo liberalismo. A encíclica traz trechos que se referem à Rússia, ao México e à Espanha. A representação do perigo comunista que se pode depreender dessas poucas citações de encíclicas é a de um sistema dentro do qual não havia lugar para a idéia de Deus, o que se conjugava com uma realidade histórica da perseguição da Igreja em regimes identificados com o comunismo. Tudo isso indicava que sob um regime comunista, a Igreja Católica teria sérios problemas de sobrevivência, o que já estaria acontecendo em países como a Rússia, o México e a Espanha.

Este perigo não tinha a mesma concretude na sociedade brasileira e especialmente nas localidades onde as pessoas entrevistadas moravam. 
Mesmo assim, parecia - pelo menos para o clero e especialmente para a hierarquia - que manifestações do perigo comunista estavam em todos os lugares e que, portanto, era preciso lutar contra ele. Era preciso mobilizar toda a estrutura da instituição para dar conta deste desafio.

Todo o trabalho de pregação anticomunista poderia estar voltado para o combate a situações concretas onde se viam indícios de subversão, mas também poderia abarcar um campo mais largo, quando o perigo comunista era relacionado com uma série de "problemas" que tinham ligação com família, comportamento, lazer, sexualidade, religião. Como procurei mostrar em O diabo é vermelho (Rodeghero, 1998), a Igreja, em sua luta contra os processos de modernização, laicização e secularização, passava a relacionar o comunismo com uma série de situações nas quais a autoridade da Igreja e o status quo fossem questionados. Esses processos ganharam grande velocidade ao longo do século XX e tiveram manifestações locais específicas.

Além disso, é preciso lembrar que também estavam em jogo as disputas políticas regionais, estaduais, nacionais e até internacionais, frente ao que a Igreja deveria se posicionar ao longo do período de 1945 e 1964, recorte da presente pesquisa. Mas, quase nada disso parece ter sido importante a ponto de ficar marcado na memória das pessoas que entrevistei.

\section{O medo do comunismo e outros medos}

Se nesses três pontos - materialismo/anticlericalismo/ateísmo, destruição das famílias e expropriação - as lembranças dos entrevistados coincidiram com os documentos da Igreja, em outros pontos elas permitiram ver associações do comunismo a alguns perigos que dificilmente apareceriam em um discurso mais letrado. Tratam-se das associações entre comunismo e algumas situações vivenciadas pelas pessoas entrevistadas ou por seus familiares. Essas situações de perigo foram diversas, mas em seu conjunto elas diziam respeito à extrapolação do poder do Estado, ao uso da violência, às lutas armadas, e à transformação de um ambiente marcado pela calma e pela ordem em outro caracterizado pela violência e pelo medo.

É preciso lembrar que, em algumas entrevistas, esses outros "perigos" foram associados propositalmente ao comunismo enquanto que, em 
outros casos, houve uma espécie de "livre associação", na qual o tema do medo do comunismo e do combate a ele tocava em lembranças como a passagem de tropas durante alguma guerra civil, o roubo de cavalos, o medo de avião, o medo em relação aos negros, etc. Alguns exemplos de como isso apareceu nas entrevistas são ilustrativos. Pe. Guerino, fazendo uma associação intencional entre dois temas, afirmou que a perseguição aos alemães e italianos em 1942 "era como o comunismo". Diferente foi o raciocínio desenvolvido por Narciso que, questionado sobre o perigo que os comunistas poderiam trazer ao Brasil, lembrou que "na época da Guerra Mundial, os padre botava medo nisso aí que foi proibido a língua italiana". Dorvalina, fazendo um movimento semelhante ao de Narciso, lembrou de um caso de roubo de cavalos quando conversávamos sobre o medo do comunismo, e disse não saber se uma coisa tinha relação com a outra. Gabriel ligou medo do comunismo com medo de avião e, depois de questionado, disse que a associação feita entre os dois temas era fruto de "grosseria".

Serão feitas, a partir de agora, reflexões sobre alguns "perigos" que os entrevistados associaram ao comunismo, especificamente sobre o contexto da passagem de tropas para uma ou outra guerra civil; o programa de nacionalização do Estado Novo; e, também no contexto da Segunda Guerra, os posicionamentos em relação ao nazismo e ao fascismo.

A associação - proposital ou livre - entre comunismo e passagem de tropas e revoltas armadas apareceu em quatro ocasiões, as quais serão brevemente apresentadas aqui. Narciso, falando sobre o medo que as pessoas tinham do comunismo, lembrou de uma revolta que aconteceu em 1930 numa localidade situada entre Passo Fundo e Marau onde "morreu muita gente. Naquela época era arma branca, facão, adaga e decerto tiro também". Isso aconteceu quando ele tinha dez anos de idade. Gabriel, por sua vez, questionado sobre o receio do comunismo quando ele era criança, lembrou que a mãe colocava nos filhos o medo do fim do mundo, o qual seria anunciado por um grande pássaro no céu, que poderia ser um teco-teco. Depois de admitir que isso não tinha nada a ver com comunismo, Gabriel, com a ajuda de seu irmão, Pe. Moisés, enveredou-se pela história de uma tropa de soldados, que durante a revolução de 1932, estacionara num potreiro próximo à sua casa e aí carneava gado. A tropa - com a qual Gabriel trocou feijão e arroz por carne - é assim descrita: "aqueles homens, negrada, fardada". 
Dorvalina foi perguntada sobre histórias a respeito do comunismo contadas em sua infância. Respondeu à pergunta dizendo que a mãe contava que os cavalos tinham que ser escondidos para não serem levados para uma revolução que ela não lembra qual era. Irmã Ida, que participava dessa conversa, lembrou então que seu pai se escondera para não ser convocado a "fazer guarda". Pe. Guerino, depois de contar o sonho que sempre tinha com uma professora espanhola sendo fuzilada pelos comunistas (havia lido isso numa revista nos anos 1930) e de que isso lhe causava medo, disse que a mãe também o amedrontava com os negros e que ele sentia medo de "qualquer coisa assim, que pudesse trazer violência". Os negros estariam ligados à revolução de 1932.

Vê-se, no conjunto dos relatos que associaram comunismo à passagem de tropas ou a revoltas armadas, algumas características comuns e que podem ser comparadas a memórias sobre a Revolução Federalista, já estudadas por René Gertz (1995). Mesmo que haja, nos exemplos citados, duas referências à Revolução de 1932, parece existir entre os entrevistados uma memória fluída sobre casos semelhantes de passagens de tropas, que faz um amálgama de outros movimentos armados ocorridos no Rio Grande do Sul, desde a Revolução Farroupilha, passando pela Federalista, pela Revolução de 1923 e chegando aos anos 1930. Na falta de estudo a respeito desse imaginário, procuro fazer algumas conexões a partir de artigos publicados sobre a Federalista.

Em estudo sobre as memórias entre teuto-brasileiros a respeito da Revolução Federalista, Gertz analisa dois surtos de publicação de obras sobre o tema. As questões que ele encontra podem ser comparadas com as acima apresentadas. Nos trabalhos que vieram a público entre 1895 e a Primeira Guerra, predominava uma visão multifacetada do movimento, que mostrava o mesmo atingindo os municípios de colonização alemã de forma muito diversa e com apoios sendo dados para os dois lados da luta. Outro surto de publicações teria aparecido nos anos 1950 e 1960, o qual teria consolidado "uma clara tendência antifederalista e destaque para as origens 'exógenas' da Revolução nas regiões de colonização alemã" (Idem, p. 112). A quase totalidade dos textos deste momento é de autoria de católicos.

Uma hipótese explicativa para essas duas diferentes formas de encarar a Revolução Federalista, segundo Gertz, relaciona a memória da revolução com o contexto da Segunda Guerra Mundial: "quanto à iniciativa 
católica [da publicação dessas obras] a Segunda Guerra, ela pode ter uma relação com os acontecimentos da própria guerra". É o que indica um dos relatos analisados pelo autor, datado de 1956 e de autoria de Michael Schauren. "Segundo ele, é incompreensível como a 'colônia alemã' tenha sofrido tanto com a assim chamada 'nacionalização' se sempre foi extremamente fiel ao governo constituído, como mostram os acontecimentos da Revolução Federalista" (Gertz, 1995, p. 113).

Em outro artigo, o mesmo autor mostra que poucas obras de caráter histórico foram escritas sobre a revolução nas regiões de colonização alemã, mas que elas criaram e difundiram a tese do caráter "exógeno" da revolução na "colônia", segundo a qual "bandos de caboclos analfabetos teriam invadido para saquear e matar indefesos cidadãos que só pensavam em trabalhar pelo seu país e pelo seu governo" (Gertz, 1993, p. 117).

No conjunto dos exemplos retirados das fontes orais, da mesma maneira, os revolucionários são apresentados como pessoas alheias ao lugar; em dois casos são representados como sendo negros; sua ação está relacionada à violência e ao saque; sua passagem ou ação causa medo. Com exceção de Dorvalina, que é luso-brasileira, os demais entrevistados são descendentes de imigrantes italianos nascidos no norte do Rio Grande do Sul.

Assim, o medo do comunismo pode ter tido - nas entrevistas - um canal de expressão na medida em que os entrevistados falaram de outro medo, que esteve mais presente na sua vida ou de seus familiares. No entanto, isso não descarta a hipótese de que as pessoas que viveram tais situações de perigo ou que ouviram seus pais falarem a respeito das mesmas acreditavam que elas eram provocadas pelos comunistas. Uma pesquisa que se preocupasse em desvendar esse imaginário relacionado à guerra civil, passagem de tropas, roubo de cavalos, recrutamento forçado de homens, poderia investigar tal hipótese.

É interessante a relação que Gertz aponta, no primeiro artigo citado, entre uma determinada narrativa sobre a Revolução Federalista e a situação da Segunda Guerra, na qual os alemães tinham que deixar claro que eram fiéis ao governo. Na presente pesquisa, a Revolução e a Guerra aparecem unidas por outro fio: falar sobre ambas tornava possível expressar o medo sentido em relação ao comunismo.

Os dois casos de relação entre comunismo e o contexto do Estado Novo e da Segunda Guerra Mundial, quando foi efetivada a campanha de 
nacionalização, que entre outras coisas, proibiu o uso da língua do alemão, do italiano e do japonês, foram levantados por descendentes de imigrantes italianos. Narciso lembrou a proibição de falar italiano, que entre os membros da sua comunidade quase ninguém falava "brasileiro" e que muitos tinham familiares na Itália. Pe. Guerino, por sua vez, tem uma lembrança do tempo do seminário. Ele é descendente de italianos, mas parece que o que mais lhe marcou foi a perseguição aos alemães tendo em vista que seus professores eram jesuítas alemães, parte dos quais, segundo ele, havia fugido de Hitler.

A proibição do uso do idioma foi traumática para os atingidos que também se tornaram alvo de denúncias e delações, o que criou um clima de silêncio e medo (Fiori, 1995). As entrevistas revelam esses sentimentos sendo relacionados e dirigidos ao comunismo. A experiência vivida no contexto da campanha de nacionalização pareceu ser uma amostra do que seria viver sob o comunismo.

Narciso também comentou que os padres amedrontavam as pessoas devido à proibição da língua, o que merece algumas palavras. Rambo (1997) explica que, desde a década de 1920, o arcebispo de Porto Alegre já orientava os padres sob a sua jurisdição para substituir, na medida do possível, o alemão pelo português nas pregações, catequese e escola. $\mathrm{Na}$ Campanha de Nacionalização, as autoridades civis tiveram a adesão formal das autoridades eclesiásticas e especialmente do arcebispo d. João Becker. Comenta, porém, que houve exemplos de resistência da parte de certos sacerdotes. Artur Isaía (1998), por sua vez, mostra que apesar dessa adesão, o arcebispo era crítico à forma como o programa de nacionalização estava sendo implantado. "D. João Becker é bastante incisivo, não na crítica ao mérito da lei da nacionalização, mas aos métodos com que o Estado Novo estava aplicando-a, gerando atritos e aproximando-se, segundo o arcebispo, de métodos nazistas" (Idem, p. 156). Parece então, que os padres devem ter se sentido obrigados a colaborar com a campanha no sentido de chamar a atenção dos fiéis a este respeito. É bem possível que muitos não tenham gostado de realizar tal tarefa já que ela vinha dificultar seu próprio trabalho pastoral.

O programa de nacionalização fez parte de uma conjuntura que está muito presente na memória dos entrevistados, a da Segunda Guerra. Pode-se dizer que - no imaginário das pessoas entrevistadas - ela serve tanto como parâmetro temporal para situar os acontecimentos (pessoais, 
locais, nacionais, internacionais) quanto como um marco de um momento histórico no qual muito se falou sobre fascismo e nazismo, mas também sobre comunismo. Em alguns casos, se descobre que houve uma simpatia temporária por Hitler, Mussolini, e também por Franco e Salazar. Aqui, estaria caracterizada mais uma situação na qual as lembranças e reflexões dos entrevistados coincidiram com posicionamentos oficiais da Igreja Católica. Nesse sentido, é importante lembrar que os posicionamentos da hierarquia católica contra o comunismo desde o período entre as duas guerras tiveram, em suas raízes, uma simpatia pelo fascismo. O contexto em que esta postura se insere é assim explicado por Beozzo (1986, p. 320): “[...] os fascismos e mesmo o nacional-socialismo, a Falange na Espanha e o salazarismo em Portugal são vistos pela Igreja como a única barreira militante que se ergue contra o comunismo". O mesmo autor destaca a simpatia católica pelo fascismo que está expressa na encíclica Quadragesimo Anno de Pio XI, escrita tem 1931. No documento, ao mesmo tempo em que o Papa condenava toda a forma de socialismo, inclusive aquela que ele chamou de "socialismo mitigado", ele fazia elogios a um tipo de corporativismo que trazia como vantagem "a pacífica colaboração de classes, a repressão das organizações e violências socialistas, a ação moderada de uma magistratura especial" (Idem, p. 312). Pio XI tece elogios a "uma nova organização sindica e corporativa surgida recentemente" que Beozzo identifica como sendo a Carta Del Lavoro do regime de Mussolini.

No que se refere ao Rio Grande do Sul, onde a Igreja tinha forte presença entre os descendentes de italianos e alemães, o arcebispo D. João Becker manifestou em diversas ocasiões - inclusive em Cartas Pastorais o seu apreço pelo fascismo e também pelo nazismo. De acordo com Isaía (1998, p. 192), “a Itália fascista era inúmeras vezes citada nos pronunciamentos oficiais da Arquidiocese como um exemplo de ordenação política capaz de perseguir a tão ansiada reforma moral da sociedade. [...] A regeneração cristã da sociedade tinha no fascismo um aliado capaz de catalisar seus propósitos".

Há semelhanças e algumas diferenças entre esses pontos de vista da hierarquia e aqueles expressos em parte das entrevistas feitas na presente pesquisa. Pe. Firmino Dalcin, entrevistado em Bagé, por exemplo, contou que a sua capacidade de distinguir entre ideologias ou regimes foi adquirida no tempo de estudo no seminário. Ele também contou que 
durante a Segunda Guerra, a questão do comunismo ficou meio de lado e o medo era dirigido ao nazismo: "Era mais o temor do nazismo. Eu estava no Seminário, na Filosofia ou na Teologia e corria a notícia de que de repente viriam os nazistas. Se lembra daquela canção de carnaval: 'quem é, quem é, quem é que tem uma cruz na testa, um bigodinho que parece mosca: é, é, palhaço’? Não é bem assim, mas é só pra te dizer que havia no carnaval uma canção anti-nazista. Depois, tínhamos professores alemães, quase todos eles. E nos contavam horrores".

Pe. Guerino, por sua vez, afirmou que apenas depois de ter entrado no seminário veio a entender o que Hitler pretendia. Ainda aos 11 anos de idade, em casa, ele lera no jornal Stafetta Riograndense (depois Correio Riograndense) uma carta do papa que condenava Hitler e o nazismo, a qual dizia que a busca de uma raça pura era algo anti-humano e anti-cristão. Mas ele lembra não ter entendido isso muito bem: "eu vim compreender isso depois que fui no seminário. Uma que nunca se ouvia falar nessa parte de doutrina, concepção".

Enquanto nas memórias de Pe. Firmino e Pe. Guerino ficou a lembrança da postura de condenação da Igreja aos regimes em questão, na de pe. Holmes e na de Pe. Moisés aparecem elementos da simpatia para com os mesmos. $\mathrm{Na}$ entrevista, questionei o primeiro sobre a Guerra Civil Espanhola, se ela fora tema de leituras no seminário e em meio a este assunto, ele colocou: "A gente pouco sabia aqui no Brasil, mas nós lemos vários livros sobre o Franco. Franco foi o grande herói que venceu os comunistas". Mais adiante, comentei que outros entrevistados me haviam dito que tinham quadros com a imagem do Mussolini nas paredes de suas casas. Pe. Holmes prosseguiu: "Então, assim, o Mussolini, ele foi muito simpático para nós de origem italiana, antes da guerra. Havia uma aceitação muito grande. Pra tu ver: muita gente sabia cantar o hino fascista [Pe. Holmes canta uns versos]. Era um canto que todo mundo cantava. Eu ouvia, passando pela rua, o pessoal cantando. É o hino do fascismo. Era 'Il Duce', o chefe. O Mussolini era simpático. Depois que ele foi morto lá e a gente soube [...] Então, culparam o Mussolini que desviou a questão, se aliou a Hitler."

Pe. Moisés, em um certo momento de sua entrevista, mencionou os nomes de Getúlio Vargas, Salazar, Franco, Mussolini e Hitler. Ele estava fazendo algumas reflexões sobre as coisas que os padres contavam a respeito do comunismo e, ao mesmo tempo, chamando a atenção para o fato 
de que não se dava uma "explicação completa" sobre o fenômeno, que não se explicavam ao povo as causas de revoluções como a russa e a cubana: "todos esses movimentos tiveram suas culpas. Como a Revolução Francesa, o comunismo na Rússia foi quando os proprietários... o povo na miséria. Em Cuba, foi um lugar explorado pelos americanos e daí deu a revolução...” E, na seqüência: "E nós tivemos a Revolução de Portugal, da Espanha [...] E a gente admirava, eu não sei não, a gente admirava o Getúlio. A gente admirava o Salazar, a gente admirava o Franco porque ele era contra o comunismo, que a gente tinha medo que o comunismo tomasse conta. A gente foi a favor do Mussolini. Em Espumoso, o pessoal todo era a favor. E era a favor de Hitler".

As posturas iniciais e públicas da Igreja Católica de apoio ao fascismo e ao nazismo foram sendo modificadas tanto no Vaticano quanto em nível local. Em 1931, Pio XI na encíclica Non abbiamo bissogno condenou as perseguições do fascismo à Ação Católica italiana, apesar de não colocar o fascismo como contrário à Igreja. A encíclica condenatória do nazismo - Mit Brennender Sorge - foi publicada em 1937 e condenava o regime como um todo. Com ela "condena-se um regime que extrapolava os limites aceitos pela Igreja na relação indivíduo-Estado" (Isaía, 1998, p. 196). Essas posições, segundo Isaía, se manifestaram na $28^{a}$ Carta Pastoral de D. João, em 1939, na qual “o nazismo aparecia como o protótipo da experiência totalitária anticristã, pregadora da divinização do Estado e do culto a seu chefe, tentando utilizar a religião apenas como auxiliar na tarefa de absorver nas mãos do governo toda a vida nacional, inclusive a espiritual. $\mathrm{O}$ fascismo italiano, ao contrário, continuava a aparecer como uma fórmula política totalmente voltada para a edificação de uma ordem cristã e respeitadora das prerrogativas da Igreja" (Idem, p. 198) Depois que o Brasil declarou guerra ao Eixo, informa o mesmo autor, D. João silenciou em relação ao fascismo italiano.

Assim, tanto por razões relacionadas ao posicionamento oficial do Vaticano no que se refere ao fascismo e ao nazismo, expressas nas posturas da hierarquia rio-grandense (D. João e os demais bispos das dioceses do Estado), quanto pelo elemento étnico que ligava descendentes de alemães e italianos à Alemanha e à Itália, é compreensível a existência de menções positivas em relação a estes regimes. Isso, por sua vez, poderia ser um elemento a mais a explicar a propensão, entre boa parte dos católicos entrevistados, em colocar-se contra o comunismo. 
Os sentimentos e lembranças em relação ao comunismo, expressos pelos entrevistados não têm relação apenas com a experiência de um ou outro, mas com um universo cultural que era aquele das comunidades católicas gaúchas do meio do século XX. Algumas diferenciações - em relação à inserção do catolicismo e à recepção do anticomunismo católico - podem ser sentidas naquelas comunidades de colonização mais antiga, habitadas por uma população majoritariamente luso-brasileira e aquelas comunidades formadas especialmente a partir da segunda metade do século XIX com imigrantes europeus, regiões que podem ser denominadas respectivamente como Campanha e Colônia.

Pelo que se viu nos comentários de leigos entrevistados, as práticas religiosas católicas eram algo muito presente entre as famílias de descendentes de imigrantes. Essa presença poderia ser algo tão "natural" a ponto das crianças brincarem de rezar missa mas, também, poderia ser algo muito opressivo, como se vê em relatos sobre a intromissão do padre nos assuntos privados e no rigor da observação à moral, à religião, aos costumes.

No caso daqueles leigos de origem luso-brasileira e que viveram parte de sua vida na zona rural da região da Campanha rio-grandense, e que descrevem as dificuldades lá enfrentadas, é importante notar que hoje eles falam a partir do lugar social de "católicos praticantes". Há muito tempo, essas pessoas vivem em cidades da região - e não mais na zona rural da sua infância - nas quais a presença da Igreja se dá especialmente por meio das paróquias e das escolas católicas, nas quais parte dos entrevistados estudaram. Tendo sido "ressocializados" neste ambiente, hoje eles têm um discurso muito semelhante àquele da instituição, segundo o qual o catolicismo prosperaria melhor nas comunidades de descendentes de imigrantes do que naquelas habitadas por luso-brasileiros ou ainda afro-brasileiros e indígenas.

Variações desse discurso já apareciam, por exemplo, em relatos do final do século XIX e início do século XX como o do Pe. Alfredo de St. Jean d'Arves, citado por Isaía (p. 33 e 34), que reclamava dos fiéis de Vacaria que só compareciam ao templo três vezes ao ano, durante as festas, buscando especialmente o baile, ou que não admitiam que o padre pregasse sobre os deveres da vida cristã ou, ainda, que alimentavam práticas supersticiosas na Sexta Feira Santa. Ao longo da primeira metade do século passado, por canais os mais diversos, a Igreja se esforçou para a 
implantação de um catolicismo renovado, lutando contra este tipo de realidade (Marin, 1992).

A pesquisa com história oral permitiu ver que há uma certa coincidência entre os relatos dos membros do clero e dos fiéis entrevistados e aqueles que os historiadores levantaram em fontes que remontam o final do século XIX. Em ambos os casos, se conclui que as comunidades de descendentes de imigrantes europeus eram mais receptivos à religião católica. Entre estes é forte a lembrança de que eram os padres aqueles que falavam contra o comunismo. Por outro lado, nas falas dos leigos que residem na região da Campanha parece se manifestar um conflito entre o que significava ter fé e o que significava ser "católico praticante". Parte dos entrevistados insiste em dizer que seus pais não podiam ir à missa, mas mesmo assim, eram católicos. Negam dessa forma, o discurso que enfatiza apenas os elementos que estariam em falta na religiosidade das populações não-descendentes de imigrantes.

Mas, qual a relação disso tudo com a recepção do anticomunismo? No conjunto das entrevistas foi possível observar que mesmo as pessoas que não tinham muito contato com a Igreja e com os padres também têm, atualmente, lembranças a respeito do anticomunismo, mas não necessariamente do católico. É o caso de Vitalina e Perciliana que ouviam críticas ao comunismo por parte dos oponentes políticos de seu irmão, que era comunista, e que não lembram se os padres falavam sobre isso; ou de Nelso que disse que ouvia falar de comunismo por meio das pessoas mais entendidas da localidade.

Parece também, pelas entrevistas, que quanto mais ligada à Igreja a pessoa era, mais ela tendia a temer o comunismo. Apesar de alguns poucos entrevistados descendentes de italianos e alemães terem afirmado que não chegaram a sentir medo do comunismo, a maioria deles revelou que esse era um sentimento forte e muito presente. Da mesma forma o fizeram os representantes do clero. Assim, se para uma parte dos entrevistados, o discurso anticomunista chegava por meio dos padres, para outros chegava por meio das pessoas envolvidas em política, ou de alguém na comunidade que parecia estar mais informado que os outros, ou que lia jornal ou tinha rádio. Mesmo que a pessoa não tenha estado em contato com o clero, o discurso anticomunista lhe atingia. As estratégias que os entrevistados usaram para falar sobre comunismo e sobre anticomunismo católico permitem sustentar que a recepção de tal discurso não foi passiva. 
Se, por um lado, revelou a forte presença entre pessoas comuns das posições tão ardentemente defendidas pela Igreja, este trabalho procurou mostrar que tal recepção foi, por outro lado, mediada por preocupações, experiências e temores diferentes, em muitos aspectos, daqueles que embasavam combate da Igreja Católica a este seu grande inimigo.

\section{Referências bibliográficas}

FIORI, Neide Almeida. Homogeneidade cultural brasileira: estratégias governamentais sob o Estado Novo. Cadernos de Sociologia. Número Especial (1995). Porto Alegre: PPGS/ UFRGS, 1995, p. 209-226.

GERTZ, René. A memória da Guerra Civil de 1893 nas regiões de colonização alemã. In: RAMBO, Arthur Blásio e FÉLIX, Loiva Otero (org.). A Revolução Federalista e os tentobrasileiros. Porto Alegre/ São Leopoldo: Editora UFRGS / Editora Unisinos, 1995.

GERTZ, René. Aspectos da Revolução Federalista nas regiões de colonização alemã. In: ALVES, Francisco das Neves e TORRES, Luiz Henrique (org.). Pensar a Revolução Federalista. Rio Grande: Editora da FURG, 1993, p. 115-121.

ISAIA, Artur César. Catolicismo e autoritarismo no Rio Grande do Sul. Porto Alegre: Edipucrs, 1998.

LEÃO XIII. Rerum Novarum. São Paulo: Edições Paulinas, 1978.

MARTINS, Marisângela. De volta para o presente: uma história dos militantes comunistas de Porto Alegre e suas representações acerca da democracia (1945-1937). Porto Alegre: UFRGS, dissertação de mestrado em História, 2007.

PIO XI. Divini Redemptoris. São Paulo: Edições Paulinas, 1965.

RODEGHERO, Carla Simone. O diabo é vermelho: imaginário anticomunista e Igreja Católica no Rio Grande do Sul (1945-1964). Passo Fundo: Ediupf, 1998.

RODEGHERO, Carla Simone. Memórias e avaliações: norte-americanos, católicos e a recepção do anticomunismo brasileiro entre 1945 e 1964. Porto Alegre: UFRGS, 2002. Tese de Doutorado em História.

RODEGHERO, Carla Simone. Viva o comunismo X Viva Cristo Rei: um estudo de recepção do anticomunismo católico a partir de fontes orais. Estudos Ibero-Americanos, v. xxxii, p. 157-173, 2006.

\section{Entrevistas citadas}

A) Entrevistas conduzidas por Carla Simone Rodeghero:

Calista Alves Machado (Iaiá), 9 de junho de 2000, Bagé. 
D. Laurindo Guizzardi, 16 de dezembro de 1999, Bagé.

Gabriel Mocelin, 22 de abril de 1999, Passo Fundo.

Horacil Dutra, 9 de junho de 2000, Bagé.

Irmã Ida Maria Carlesso e Dorvalina Peres Viana, 16 de junho de 2000, Santana do Livramento. Irma Saenger Ribeiro e Nelso da Silva Ribeiro, 15 de junho de 2000, Alegrete.

Jandir Zanotelli, 23 de setembro de 1999, Pelotas.

Maria Neiva Vaz Huber e Augusto Ludovico Huber, 8 de junho de 2000, Bagé.

Nelsy Elli e Cláudio Utzig, 26 de maio de 1999, Carazinho.

Pe. Firmino Dalcin, 08 de junho de 2000, Bagé.

Pe. Guerino Parizotto, 25 de julho de 1997, Passo Fundo.

Pe. Holmes Conzatti, 15 de junho de 2000, Alegrete.

Pe. Moisés Mocelin, 22 de abril de 1999, Passo Fundo.

Perciliana da Costa Motta e Vitalina da Costa Ribeiro, 15 de junho de 2000, Alegrete.

B) Entrevistas conduzidas por Márcia do Nascimento (Bolsa de Iniciação Científica - Fapergs/ UPF) sob orientação de Carla Simone Rodeghero:

Carino Corso, 30 de agosto de 1997, Passo Fundo.

José Abraão Rigo, 8 de agosto de 1997, Marau.

Narciso Tesser, 8 de agosto de 1997, Marau.

Resumo: O objetivo do texto é analisar as lembranças que um grupo de católicos gaúchos tem da pregação da Igreja sobre o comunismo e do medo que era sentido em relação a isso, no período de 1945 a 1964. Explora as dificuldades que estas pessoas tiveram para tratar do tema, bem como as estratégias que elas usaram para se expressar. É resultado de uma pesquisa mais ampla que discute o imaginário anticomunista sob o ponto de vista da recepção, buscando compreender como os destinatários do anticomunismo católico o recebiam e que tipo de transformações e permanências ocorrem no processo de recepção.

Palavras-chave: anticomunismo católico; recepção; medo; memória.

\section{Communism and other dangers: memories of the fear among Catholics}

Abstract: The central aim of paper is to analyze how a group of Catholics, in Rio Grande do Sul, remembers today the Church's fight and fear against communism, from 1945 to 1964. It discusses the difficulties these people had/have to talk about the theme, as well as the strategies they use to express themselves. The paper takes part in a broader research that focuses the anticommunist imaginary asking about its reception among "common people".

Keywords: Catholic anti-communism; reception; fear; memory. 